УДК 37.017

DOI: $10.17223 / 23062061 / 24 / 6$

\title{
Е.Ю. Ромашина
}

\section{ТЕКСТ И ОБРАЗ: РАЗГОВОР НА РАЗНЫХ ЯЗЫКАХ (КНИЖНАЯ ГРАФИКА ОСКАРА ПЛЕТЧА В ГЕРМАНИИ, АНГЛИИ И РОССИИ)}

\begin{abstract}
Аннотация. $B$ Eвропе второй половины XIX в. массовым явлением книгоиздательской практики стала детская книжка с картинками. Развитие полиграфической техники, становление психологии как научного знания, совершенствование методик образовательного взаимодействия взрослого и ребенка, - все эти факторы обусловили появление изданий для детей, предполагающих не только чтение вслух, но и разглядывание рисунков. Однако взаимосвязи между текстуальным и визуальным нарративами книг еще не были прочны. По экономическим причинам одни и те же иллюстрачии нередко использовались в сочетании с разными текстами, переводы и переиздания добавляли разночтений. Данные положения в настоящей статье подтверждень материалами анализа немецких, русских и английских изданий с рисунками Оскара Плетча (1830-1888). Рассмотрены сюжеты, созданные художником, сопоставлены тексты на трех языках. Выявлены варианты интерпретации рисунков, возникаюшие трансформации смыслов; определена тенденции использования визуальных материалов в дидактических иелях.
\end{abstract}

Ключевые слова: детская литература, книжная графика, визуальный нарратив, Оскар Плетч, перевод.

K середине XIX столетия существенное удешевление и упрощение процессов изготовления иллюминированной печатной продукции в европейской издательской практике превратило детскую «книжку с картинками» в явление массовой культуры. Изображения многократно воспроизводились, тиражировались, складывались в последовательности и серии. Распространение такого рода книжной продукции, усиление ее места и роли в культуре способствовали проникновению образов в сферу повседневного опыта детей и взрослых. Складывался и активно развивался новый жанр детской литературы, предполагающий чтение вслух и подробное разглядывание картинок взрослым вместе с ребенком. Однако взаимосвязь изображения и слова в книге того времени не была прочной: целенаправленный заказ 
и изготовление рисунка к тексту были весьма недешевы, и потому издательства нередко использовали готовые клише, так сказать «подержанный товар», «второй тираж» книжного рынка, покупая или беря на прокат необходимые политипажи [1. С. 233]. Таким образом, одни и те же иллюстрации могли соседствовать с разными текстами незначительно, а иногда и достаточно сильно отличающимися. Переводы и переиздания детской иллюстрированной литературы в других странах добавляли разночтений: стремления издателей и переводчиков адаптировать текст к реалиям другого языка и культуры, несформированность авторского права, просто ошибки и возникающие технические проблемы (например, размеры отведенного на странице пространства), - все это приводило к тому, что текстуальный и визуальный нарративы могли «расходиться» весьма значительно.

Мы рассмотрим ряд детских книг с рисунками одного автора, которые были изданы на протяжении второй половины XIX в. в Германии, Великобритании и России. Проанализируем сюжеты, созданные художником, и сравним комментарии, пояснения и дополнения этих сюжетов на трех языках.

Художник, о котором пойдет речь, - Оскар Плетч (Oscar Pletsch, 1830-1888). Он родился в Берлине и учился в Академии художеств в Дрездене, в классах Людвига Рихтера и Эдуарда Бендемана. Для творчества им изначально был избран жанр «бытовой» живописи с мотивами повседневной семейной жизни. Первый большой успех к нему пришел после создания иллюстрированной книги Die Kinderstube / Детская [2]. Позднее Плетч много работал для издательства Alphons Dürr в Лейпциге, его рисунки публиковались в Англии, Франции, Швеции, России и США.

Помимо «Детской» мы рассмотрим альбом Gute Freundschaft / Тесная дружба [3], сборники стихов Kleines Volk / Маленькие люди [4] и Allerlei Schnik-Schnak / Всевозможная ерунда [5], изданные в Германии; их переводы на русский [6-8]; Child-land / Детский мир [9] - на английском языке; а также российские издания, не имевшие текстуальных аналогов в Европе, но включавшие в себя рисунки Плетча [10].

Нас будет интересовать не только единый изобразительный канон, заданный рисунками Оскара Плетча (в общей сложности около 200 иллюстраций), но и текстуальные отличия указанных изданий. Для начала коротко охарактеризуем их. 
Die Kinderstube увидела свет в Гамбурге в 1860 г. Книга вышла с посвящением наследному принцу Фридриху Уильяму Виктору Альберту Прусскому - будущему императору Вильгельму II (1859-1917), титульный лист содержал указание, что оригиналы рисунков находятся в собственности Его высочества. Это был дар художника к рождению кронпринца. Не исключено, что такой «рекламный шаг» немало способствовал популярности издания и отчасти обеспечил его успех. 36 картин Плетча были гравированы Августом Габером (1823-1894) постоянным сотрудником его учителя Людвига Рихтера. Die Kinderstube выдержала множество переизданий, de visu мы познакомились с третьим. Книгу открывало стихотворное предисловие самого О. Плетча, датированное июнем 1859 г. Этот удивительный текст настоящий мостик между мирами: внутренним миром самого художника, рисованным «весенним миром детства», и пространством непростой «взрослой» реальности.

27 апреля 1859 г. обострилось военное противостояние Франции и Австрии в борьбе за контроль над землями северной Италии. Германский союз не вмешивался в боевые действия, но мобилизация была объявлена. Среди других «под ружье» был поставлен никому не известный художник, молодой муж и отец - Оскар Плетч. Отправляясь в ополчение, он следующим образом распорядился накопленным к тому времени творческим богатством:

Любимый принц, к тебе пришел

Верный канонир-ополченец,

Он лучше всех палит из пушки,

Это для него как стих и рифма.

А если плоха моя поэма,

Любимый принц, не презирай еe!

Эти строки - дикорастущие цветы:

Мошенник норовит отдать больше, чем имеет.

Я - художник, плох и прав,

Ребенок музы и музы раб.

Ей верен - вольный я наемник -

Своими кистью и мольбертом.

Я много рисовал картин

Для взрослых - старых и разумных;

Но гораздо больше нравится мне

Детства мир золотой! 
У самого в доме есть любимый ребенок Расцветающий бутон, преддверие весны; Он с ног до головы размером с три туфли, Любим и мил, также как ты.

Когда мать принесла мне его, И он протянул ко мне свои ручонки, Когда улыбнулся и задорно засмеялся, Я почувствовал себя счастливым.

Время детства, прекрасное время, Полное весенней радости и песен Твою птичью жизнь я ухватил В книжку с картинками поместил.

Что за небесное сокровище есть В хижине и в золотом дворце? Я нарисую его старательным карандашом И от этого сам стану молодым.

Еще не окончена моя книга, Но гремят вдали выстрел за выстрелом; Фыркает конь в предчувствии битвы с франками, Барабан зовет: проснись! очнись!

Прощай, мой дорогой мольберт!

Прощайте кисть и карандаш!

Прощай, моя жена, и любимый ребенок, Бутон, рождающий весну!

Я оставляю вас одних -

Боже, теперь ты их единственный щит! Ещё один поклон, еще один поцелуй, А теперь я должен маршировать!

И когда было пролито достаточно слёз, На глаза мне попалась моя книга с картинками. Она посмотрела на меня и спросила: Скажи, Пока ты маршируешь, где же буду я?

И когда я пел, и когда думал, Кому завещаю свою книгу с картинами, Дорогой принц, я подумал - тебе, Может быть, она обрадует тебя. 
И пришел я к тебе, таким, каков есть,

И склоняюсь пред твоей колыбелью.

Пусть навек Бог продлит твою

Весеннюю пору детства!

Чтоб защищал Он сильной рукой

Твой родной дом, твою Отчизну!

Возлюбленный принц, вот чего желает тебе

Твой преданный канонир.

Берлин, июнь $1859^{1}$.

Изложенная в стихах история имела место в действительности: появление в семье художника первенца вдохновило его на серию «рисунков из детской» - достоверных, трогательных и обаятельных, какие «мог сделать только человек, который живет домом и семьей, находит в них свой мир, центр своих чувств и разума, свои мысли и заботы» [11]. И, отправляясь в ополчение, Плетч действительно подарил их кронпринцу. Напряженность международного конфликта отступила быстро, участвовать в боевых действиях художнику не пришлось. А книга вскоре увидела свет. В России отдельным изданием она не выходила.

Gute Freundschaft / Тесная дружба - это альбом, составленный из 21 картины О. Плетча с краткими подписями к ним. Книга имела подзаголовок: Eine Erzählung für Damen aber für Kleine / История для дам, но самых маленьких. Основной смысловой ряд издания - визуальный: иллюстрации представляли собой связный и последовательный рассказ об одном дне двух девочек - постарше и помладше (кузин, как мы узнаем из текста). Рассказ начинался с рисунка, на котором девочка с куклой под мышкой звонит в дверь (на табличке имя хозяина: O. Pletsch) и спрашивает: «Она дома?». Далее мы видим, как подруги разговаривают, играют, затевают большую стирку, секретничают, ссорятся, мирятся и, наконец, прощаются с читателем / зрителем, «понарошку» отправляясь в путешествие. Все иллюстрации датированы 1863-м годом, вероятно, они изначально задумывались и создавались Плетчем как серия.

\footnotetext{
1 Здесь и далее переводы с немецкого Анны Безбородовой. Автор выражает признательность переводчику за интерес к теме, бескорыстную и квалифицированную помощь.
} 
Русский перевод «Тесной дружбы» был выпущен в Петербурге в 1869 г. (установлен библиографами) издательством М.О. Вольфа известным своими иллюстрированными книгами для детей $[12,13]$. В этой версии 24 картины; три дополнительные рисунка, вероятно, взяты из более позднего немецкого переиздания: они датированы 1867 годом, но вполне вписываются в общую ленту повествования, героини на них те же. Подписи ко всем рисункам были переведены на русский достаточно точно по смыслу, хотя и не буквально: $A$ mеперь мы должны постирать превратилось в Послушай, на днях нам надо будет стирать белье; С большим чувством! - в С чувством, с толком, с расстановкой! и т.д. Тем самым тексты получили несколько иные коннотации, а картинки - прочитываемые смыслы. Однако интереснее другое. В издании Вольфа помимо подписей-пояснений к иллюстрациям появились стихотворения, о них мы скажем ниже.

Стихотворный сборник Kleines Volk: 20 Charakterzeichnungen von Oskar Pletsch в русском переводе получил название «Маленькие люди» - хотя, конечно, оригинал ближе по смыслу к словосочетанию «маленький народец». Вышел в свет он в 1869 г. также в издательстве М. Вольфа. В подзаголовке было указано: «16 характеристических рисунков Оскара Плетча». Непонятно, почему при переводе книга утратила 4 иллюстрации, во всяком случае, содержательно это необъяснимо; зато 16 страниц - полный печатный лист, и с точки зрения типографских работ такое издание, вероятно, экономически оказалось более выгодным.

Allerlei Schnik-Schnak была издана в России под названием «Первые шаги жизни: Очерки с натуры» тем же М.О. Вольфом (187-?). Здесь сокращение оказалось еще более существенным - вместо 48 картин немецкого сборника в русский вариант вошли 32 (опять же ровно 2 печатных листа).

На титуле всех трех изданий значилось: текст автора «Степкирастрепки», т.е., надо понимать, Генриха Гофмана ${ }^{1}$. Однако сравни-

\footnotetext{
${ }^{1}$ Генрих Гофман (1809-1894) - врач-психиатр из Франкфурта. В 1844 г. на Рождество он подарил своему трехлетнему сыну самодельный рукописный сборник стихов и картинок о том, что надо умываться и стричь ногти, есть суп, не играть со спичками и т.д., и о том, что случится, если этого не делать. Друзья убедили доктора, что книгу стоит издать, и в 1845 г. появились Lustige Geschichten und
} 
тельный анализ немецких оригиналов и русских переводов продемонстрировал, что это не так. Помимо Struwwelpeter Гофман являлся автором целого ряда детских стихов (например, сборника ImHimmel und auf de Erde. Herzliches und Scherzliches aus der Kinderwelt / В небесах и на земле. Задушевное и веселое из детского мира, 1857), однако, как мы знаем, Gute Freundschaft вовсе не содержала сколько-нибудь развернутых текстов; стихи, помещенные в Kleines Volk принадлежали перу Фридриха Ольденберга (Friedrich Oldenberg, 1820-1895), автор текстов в Allerlei Schnik-Schnak - Э. М. Арндт ${ }^{1}$. Все эти данные указаны в оригинальных немецких изданиях. Вероятно, речь должна идти не об авторе «страшилок» про Неряху-Петера, а о переводчике, подарившем России собственно Степку-растрепку. Его имя неизвестно: ни сами издания, ни каталоги Вольфа сведений о нем не содержат ${ }^{2}$.

Child-land / Детский мир: книжка с картинками для самых маленьких была издана в Лондоне в 1873 г. На ее страницах около 200 иллюстраций, 107 из них - Оскара Плетча. Рисунки атрибутированы нами либо по авторской монограмме художника: переплетенные буквы О и Р (часто в обрамлении года создания работы), либо на основании сравнения с другими рассмотренными изданиями.

drollige Bilder für Kinder von 3-6 Jahren / Веселые истории и забавные картинки для детей от 3 до 6 лет. В 1847 г. (в 4-м издании) сборник пополнился новыми сюжетами, обрел название Struwwelpeter / Неряха-Петер и начал свое триумфальное шествие по миру детской литературы. В противовес скучно-назидательным текстам середины XIX в. «ужастики» Гофмана стали очень популярны и любимы детьми. Стихи исполнялись на детских концертах, перерабатывались для любительских постановок, издавались во всех европейских странах (английский перевод - Марка Твена), в Германии - более сотни раз. На русском книжка появилась в 1849 г. с заголовком «Степка-растрепка», и в этой версии до 1914 г. была переиздана 10 раз (тип. Х. Гинце; т-во М.О. Вольфа) [14]. В других (иногда весьма вольных) переводах и с другими иллюстрациями полюбившиеся рассказы в России выходили у А.Д. Ступина, И.Д. Сытина, И. Кнебель и др.

${ }^{1}$ Арндт Эрнст Мориц (Ernst Moritz Arndt; 1769-1860) - немецкий писатель, известен как публицист, драматург, историк. Автор целого ряда произведений для детей.

${ }^{2}$ В каталоге Российской национальной библиотеки как составитель (?) «Маленьких людей» (СПб, 1869) указан Иван Казимирович Кондратьев (1849-1904), поэтпесенник и драматург. Но в силу возраста автором «Степки-растрепки» он быть не может. 
В английском «Детском мире» использованы все иллюстрации (21) из GuteFreundschaft (1865), все 20 из Kleines Volk, около 20 из Allerlei Schnik-Schnak (1866), 6 - из Die Kinderstube (1860), остальные - вероятно, из других аналогичных немецких (?) изданий. Их путь в Лондон нам проследить не удалось, можем сказать только, что издательство Самюэля Партриджа (S.W. Partridge \& $\mathrm{C}^{\circ}$ ) достаточно активно выпускало иллюстрированные издания для детей [15]. Каждая иллюстрация помещена на отдельной странице и сопровождена коротким рассказом в прозе.

Итак, насколько же «разошлись» немецкие, английские и русские тексты, в разных изданиях сопутствующие рисункам Плетча? Повлияло ли это на интерпретацию визуальных сюжетов?

Сразу коротко ответим - да. И настолько сильно, что вызывает оторопь у современного читателя. Причем отметим, что М.О. Вольф обошелся с немецкими оригиналами намного «бережнее», нежели его английские коллеги.

Начнем свой анализ с Gute Freundschaft. В русском переводе «Тесная дружба» обрела стихотворные подписи к рисункам. Большинство из них представляют собой прямую речь - монолог или диалог героинь, изображенных на картине. Тексты по-детски эмоциональны, непосредственны, и иногда нарочито нескладны (рис. 1).

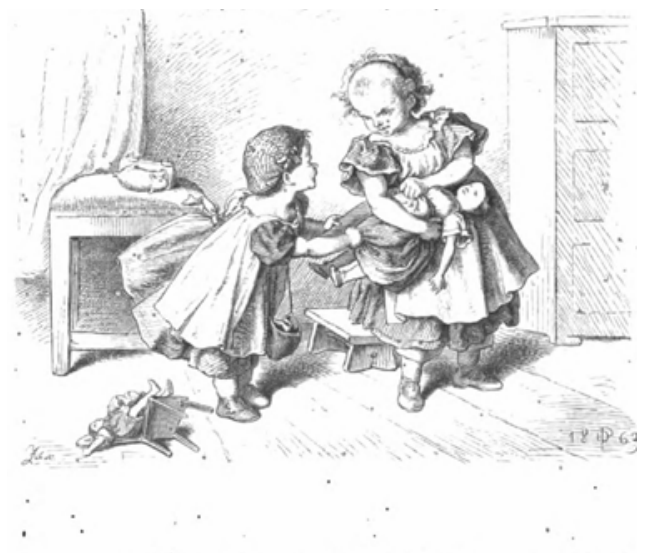

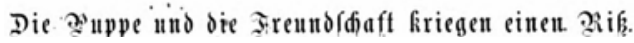

Pис. 1. Gute Freundschaft. Berlin, 1865. S. 16 


\section{И кукла, и дружба начинают рваться}

«Отдай мне куклу!» - «Вот еще!»

- «Я маменьке скажу!»

- «Ну, перестань реветь! А то

Я в угол засажу!»

- «Не смеешь ты!» - «Ну, не отдам!»

- «Ты все себе берешь!»

- «Пусти же! Кукле пополам

Ты платье разорвешь!» [6. С. 19].

Там, где рассказ ведется от имени взрослого, слышатся другие интонации: прежде всего, ирония, взгляд со стороны доброжелательного, чуть снисходительного старшего, не относящегося всерьез к детским забавам, но потихоньку любующегося ими (рис. 2).

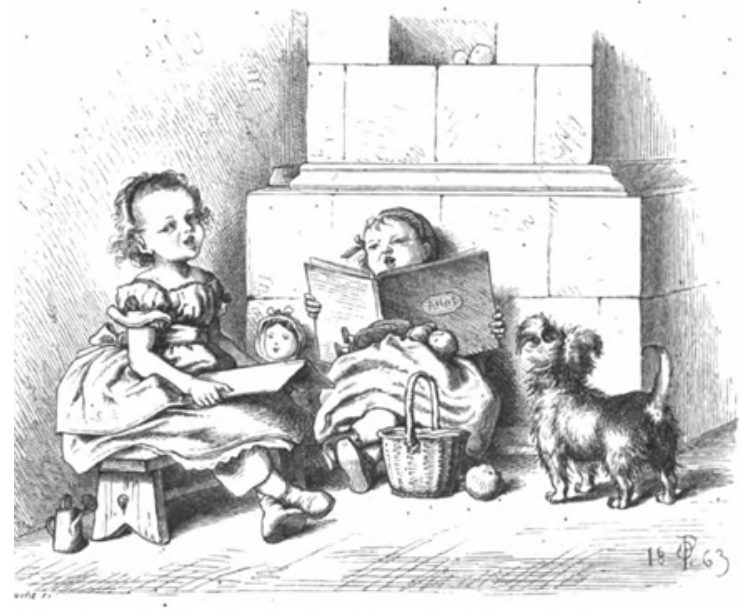

\section{Pengemein gefüflvold!}

Рис. 2. Gute Freundschaft. Berlin, 1865. S. 16

С чувством, с толком, с расстановкой

Они поют, поют с глубоким тонким чувством

И восхищаются музыкою своей.

Но как доволен бы остался их искусством

Известный дедушки-Крылова соловей? [6. С. 19] 
Английский издатель серию «рассыпал»: рисунки из Gute Freundschaft в Child-land вошли все, но размещены они были в произвольном порядке, вперемешку с другими иллюстрациями, без соблюдения логики взаимоотношений двух подруг. Одна и та же героиня названа разными именами (она и Лора, и Мария, и Джейн), стирка предшествует раздеванию кукол, сломанная кукла - ссоре и т.д. Впрочем, в английском издании есть тексты, аналогичные немецким заголовкам и русским стихам (рис. 3).

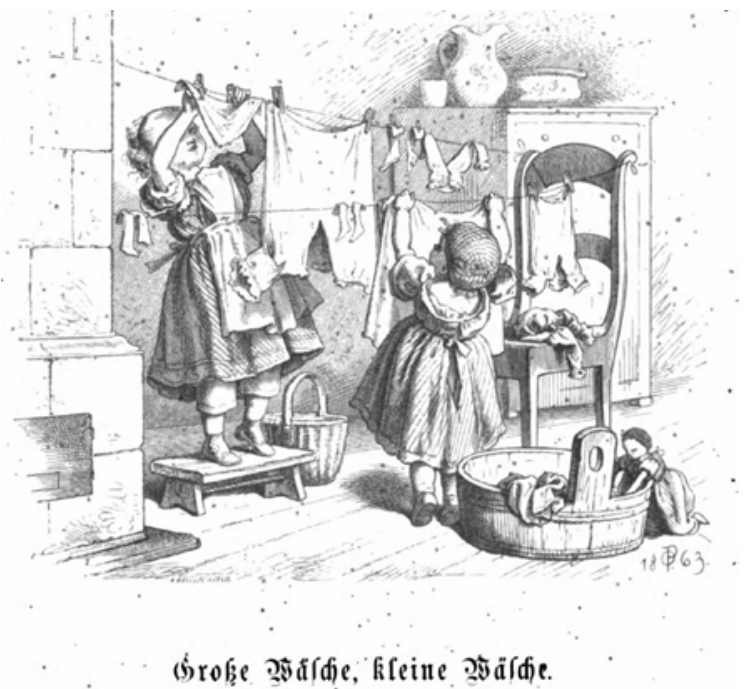

Рис. 3. Gute Freundschaft. Berlin, 1865. S. 6

\section{Большая стирка}

Юбочки, платочки,

Чепчики, чулочки,

Рукава, косынки,

Платья, пелеринки,

Скатерти, салфетки -

И вас моем, детки!

Пропасть нам работы!

Много нам заботы!

Холим вас и гладим,

Чешем вас и рядим;

А вы, наши пташки,

Вечно замарашки [6. С. 5].

\section{Кукольная стирка}

Это очень серьезно, когда приходит день кукольной стирки. В детской помещена большая лохань с мокрой одеждой и развешены веревки для просушки. Наши две маленькие подруги крайне заняты, и они должны поспешить, потому что папа не хотел бы, чтобы его маленькие девочки отсутствовали, когда он приходит домой [9. Р. 33]. 
Подчеркнем, что здесь русский переводчик прошел мимо одного нюанса сюжета, а английский - мимо другого. Подпись на немецком означает «Большая стирка, маленькая стирка». На рисунке мы видим девочек, развешивающих на веревке хоть и маленькие, но не кукольные, а скорее собственные, детские, вещи. А рядом кукла достирывает свои. В русском издании текст имеет заголовок «Большая стирка»: героини рассказывают, как они заботятся о «детках-замарашках». Английский вариант - «Кукольная стирка», но текст имеет смысл, аналогичный русскому варианту. Рисунок Плетча тоньше и интереснее, тексты явно «не дотягивают» до него.

Вместе с тем в Child-land довольно много рассказов, которые вовсе не совпадают по смыслу с сюжетной линией Gute Freundschaft. «Выдернутые» из контекста рисунки интерпретированы удивительным образом. Иногда нейтрально, хотя и «не о том» (рис. 4), а иногда жестам и движениям детей приписаны иные, причем резко отрицательные характеристики (см. рис. 5).

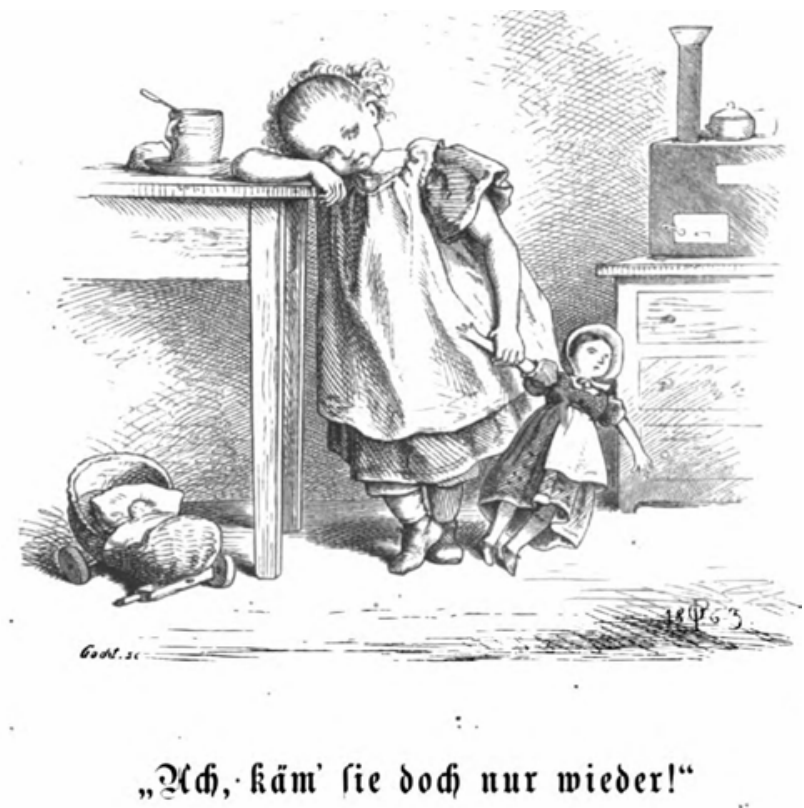

Рис. 4. Только, пожалуйста, вернись! Gute Freundschaft. Berlin, 1865. S. 19 
Ax, когда б она опять пришла!

И грустно мне, и скучно мне.

И все мне опостыло!

И на яву я, и во сне

Все думаю, как было!

Когда б пришла она скорей

Как прежде приходила, Я б бросилась на шею ей И все бы ей простила! [6. С. 22].

\section{Что делать дальше?}

Сыро, и маленькая Лора не может выйти. Так что она играла дома, и развлекалась со своими куклами. Но дождь все идет, она устала от своих кукол, и спрашивает: что делать дальше, чтобы развлечься. Она должна иметь терпение, а папа скоро будет дома к чаю [9. Р. 64].

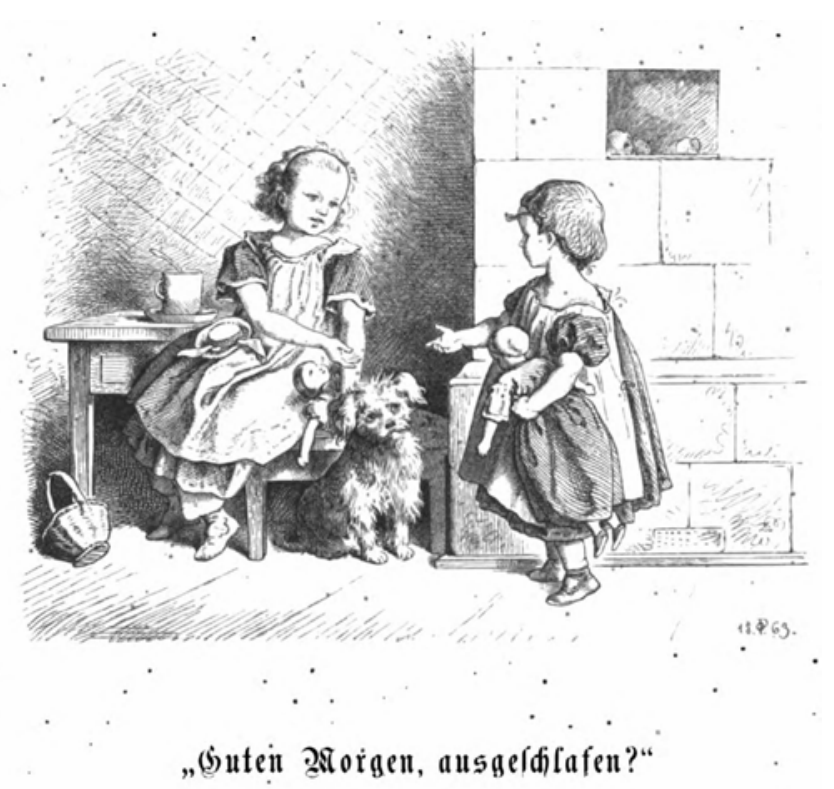

Рис. 5. Доброе утро, как спалось? Gute Freundschaft. Berlin, 1865. S. 3

\section{Здравствуй! Ты выспалась?} Здравствуй! Как ты отдыхала?

Что ты видела во сне?

Ты не думала ни мало, Полагаю, обо мне?

От тебя ж мне нет покою; Нет терпенья утра ждать! Так мне хочется с тобою Все болтать, да все играть! [6. С. 3]

\section{Обмен куклами}

Каждой из кузин надоели ее собственные куклы, и они хотели бы обменяться. Но они не доверяют друг другу, и потому каждая протягивает руку, но ни одна из них, кажется, не готова отдать куклу первой. Даже собака выглядит удивленной [9. Р. 119] 
Кажется невероятным, но в ряде случаев переводчики даже «эмоционально нагрузили» изображения совсем иначе. Подруги ссорятся, одна из них уходит, а оставшаяся играет с куклами в одиночестве, делая вид, что так ей больше нравится. Русский переводчик «повышает градус» ситуации, английский «замораживает» конфликт:

\section{Туда тебе дорога!}

Пожалуй! Пусть себе идет!

Ведь мне ее не надо!

Она мне все одно поет, Что быть мне с ней отрада. Ни чуть! Мне видеться с такой Невежей нет желанья! Мне будет веселей одной. Прегадкое созданье! [6. С. 21]

\section{Странное место для куклы}

Малышка забрела в пустую комнату, где папа хранит старые книги, но сама она очень редко заходит сюда. Она принесла с собой две куклы, одну из которых усадила в корзину, а для другой нашла место на большой старой книге с застежкой. Папа мало думает о том, что делает ребенок, но полагаю, ее скоро хватятся и тогда найдут здесь очень занятой [9. Р. 160].

Обратим внимание, что во многих английских текстах фигурирует герой, которого нет на рисунках, - папа. Это незримая «высшая сила»: как только она является, любая игра должна быть окончена, а умытые, тихие дети обязаны послушно предстать перед ней. Такого поворота событий нет у Плетча, нет его и в русских стихах.

Переходя к анализу следующих изданий, отметим общую для всех сюжетов особенность английского «Детского мира» - в своих текстах эта книга гораздо более дидактична и назидательна, нежели немецкие оригиналы и русские переводы.

Die Kinderstube на русском языке не выходила, и потому сравнить ее мы можем только с английским изданием. Приведем всего два примера, демонстрирующих, насколько существенной могла быть трансформация. В данном случае не приходится даже говорить о переводе: текст повествует совсем о другом, полностью меняет смысл рисунка и зачастую уводит сюжет от экзистенциальных вопросов в бытовую сферу и обратно, задавая движение в противоположных направлениях (см. рис. 6, 7).

Обратимся к сборнику Allerlei Schnik-Schnak (в русской версии Первые шаги жизни) и обнаружим ту же тенденцию: издательством M.O. Вольфа был осуществлен перевод этой книги, публикация S.W. Partridge \& $\mathrm{C}^{\circ}$ переводом не является. 


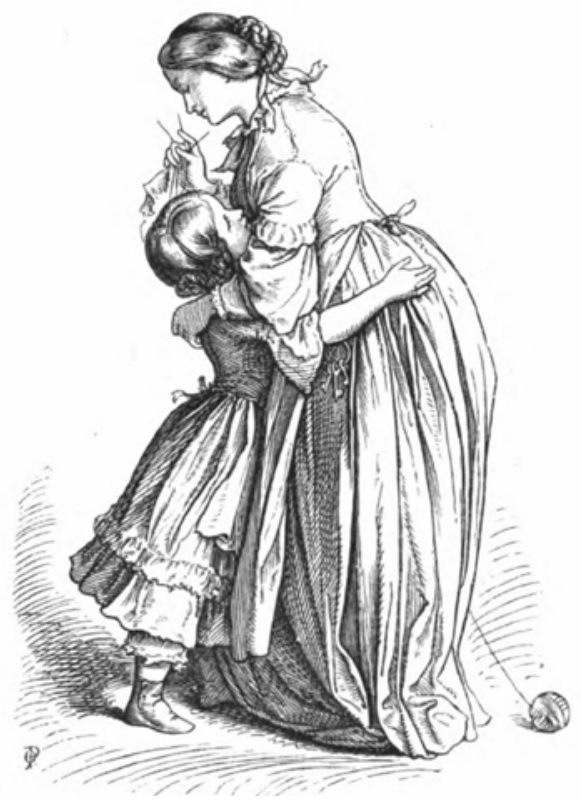

Рис. 6. Die Kinderstube. Hamburg, 1860

Милое дитя, ты - все, Что есть у меня на Земле, И буду плакать я о тебе, Когда в могилу сойду [2. S. 40].
«Мама, я так тебя люблю»

Этель - любящая маленькая девочка, всегда обнимает свою маму. Мама хочет заняться вязанием, но Этель обнимает ее и говорит: «Мама, я так люблю тебя». Боюсь, мама не сможет вязать, пока Этель прерывает ее таким образом [9. Р. 141].

Автор-англичанин составил свои тексты, ориентируясь, видимо, только на изображения. В ряде очевидных случаев сюжет, конечно, совпадает, но и очень много «промахов», в том числе в «дешифровке» и трансляции эмоционального состояния героев иллюстрации. Отметим, что английская версия во всех возможных случаях готова трактовать сюжет как некую воспитательную ситуацию: девочка наряжается - чтобы идти в школу; речь малыша перед друзьями (в оригина- 
ле - пародия на проповедь) - викторина с яблоком-призом; беседа двух детей - повторение уроков и т.п. (см. рис. 8).

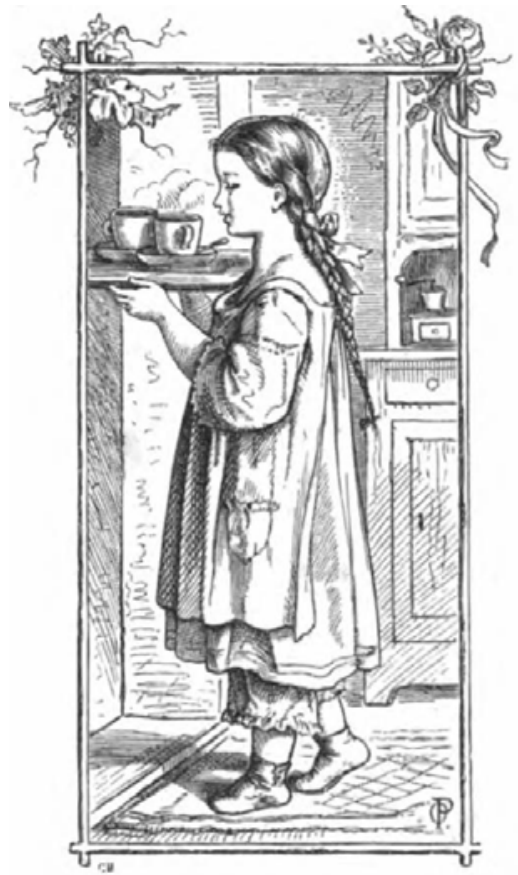

Рис. 7. Die Kinderstube.Hamburg, 1860. S. 36

А тут входит прелестная

Юная фройлян Элизабет.

«Уважаемый папа и

Уважаемая мама,

Смотрите, кофе готов!

Не поискать ли в шкафу?

Есть кусочек пирога».

- Поставь поднос сюда;

Спасибо тебе, Элизабет!

Подойди, любимая, дай руку!

Да ты разгорячилась на бегу.

Твоя забота - всегда подарок,

Не хочешь ли сама чашечку? [2. S. 36]

\section{Завтрак для мамы}

Мама нехорошо себя чувствует этим утром, потому что вчерашним холодным днем она ходила по мокрым полям, чтобы навестить бедного умирающего человека. Поэтому она встает не так рано, как обычно, и Гарриет несет ей чашку горячего кофе. Гарриет не позволит маме ждать служанку, когда она больна, она сама может уделить ей больше внимания. Она идет на цыпочках, избегая шума, поскольку больным нравится быть в тишине [9. Р. 140]. 


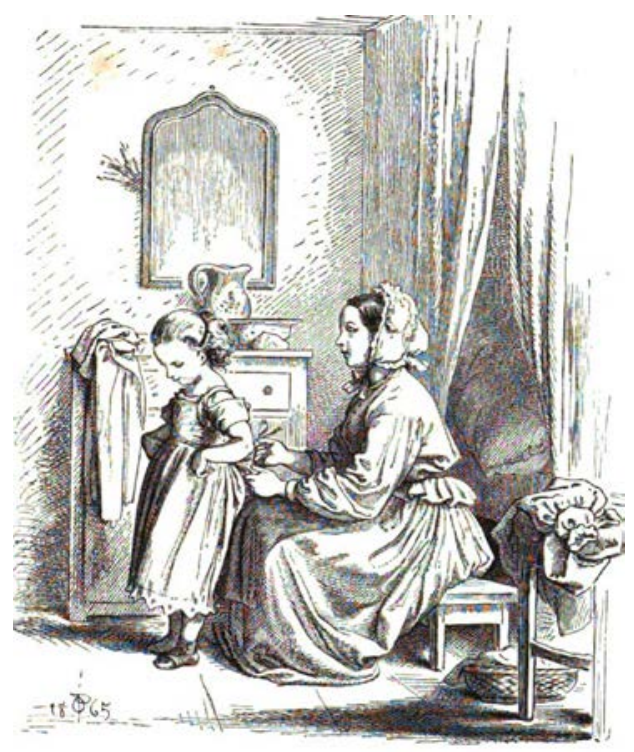

Рис. 8. Allerlei Schnik-Schnak, Leipzig, 1866. S. 32

Такая хрупкая и милая, так непорочно и нежно Сложена маленькая Лизбет!

Юбочка бело-фиолетовая, Такая чистая и свежевыглаженная, Платьице от Яконнет, Новехонький корсет, Какая хрупкая и милая, так непорочно и нежно Выглядит сегодня Лизбет! [5. S. 32]
Как разодета

Наша Лизета!

Словно большая

Дама какая!

Счету нет сборочкам, Строчкам, оборочкам, Дырочкам, зубчикам, Тоненьким рубчикам.

Что за сапожки! -

Чудо в них ножки!

Взорам отрадно,

Так ты нарядна! [8. С. 17]

\section{Почти одета}

Матильда почти одета. Она будет готова к завтраку через несколько минут, и тогда надо спешить в школу [9. P. 167].

Те же особенности перевода можно обнаружить при сравнении немецкого оригинала Kleines Volk с русской и английской версиями (см. рис. 9). 


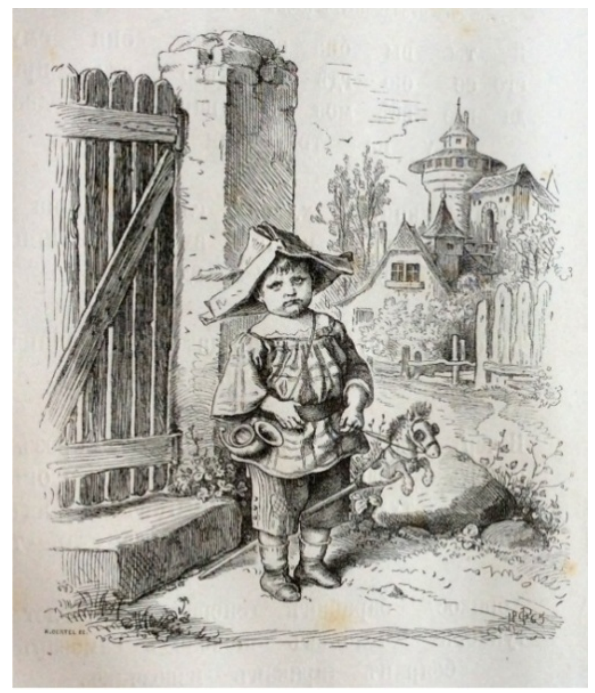

Puc. 9. KleinesVolk. Berlin, 1865. S. 1

\section{В плохом настроении}

Что ты бурчишь, любимый малыш, И насупился как крот? Другие мальчишки Бросили тебя? Или ударил какой-то грубиян? Или напала тоска? Или французы порвали тебе штаны? Взбодрись, прыгай прямо на коня! Тогда мужество сразу вернется [4. S. 1].
Подо мною конь ретивый Гордо расправляет стан, И над шляпою красивый Развевается султан.

А все как-то неподручно И неладно мне вполне. Да, мне скучно, скучно, скучно; Оттого, что скучно мне! [7. C. 6]
Конь Альберта Альберт любит скакать на деревянной лошадке, с рогом на боку [9. P. 138].

В целом повторим, что российские издатели ближе к замыслу художника и авторов немецких стихов. Однако не во всех книгах это так.

Мы упоминали, что рисунки Плетча использовались в России и в качестве иллюстраций к оригинальным текстам, никак не связанным с европейскими. В этом случае «расстояние» от буквы до образа иногда 
оказывалось очень большим: текстуальный нарратив говорил читателю об одном, визуальный - совсем о другом. Яркий пример - 10-е издание азбуки «Елка» А.М. Дараган. Это роскошный подарочный альбом, текст которого полностью повторял предыдущие девять изданий (первое - 1845 г.), но иллюстрации были заменены практически полностью: Вольф использовал работы известных российских и европейских художников (Георга Мейера, Лоренца Фрёлиха (Lorenz Frølich), Генриха Пиллати (Henryk Pillati), Эмиля Байарда (Émile-Antoine Bayard), Жана Муане (Jean-Pierre Moynet) u дp.). Оскару Плетчу в этом издании принадлежали 7 иллюстраций, датированных 1863 и 1865 гг.: 2 из Gute Freundschaft; 4 - из Kleines Volk; 1 - из Allerlei Schnik-Schnak (все семь представлены в английском Child-land). Тексты азбуки Дараган не имели ничего общего ни с одним из этих изданий. Мало того, в альбоме иллюстрации и текст совершенно не соотносились друг с другом. Даже там, где имелись прямые «отсылки» к рисункам - Что нарисовано здесь? Рыбак... - они «не работали»: вместо рыбака читатель видел солдатскую казарму, вместо семьи, о которой шла речь в тексте, - охоту на зайца и т.п. Главный мотив отбора иллюстративного материала оказался «украшательским», декоративным, но не учебным, что демонстрирует, как непрочны были еще связи между визуальным рядом и текстом в российской литературе для детей.

Итак, анализ изданий и сопоставление их сюжетов - вербальных и визуальных - позволили нам определить характер взаимоотношений и взаимосвязей их текстов и образов как «разговор на разных языках». Причиной «разноголосицы» были не только сущностные отличия слова от изображения, но и проблемы перевода, общие изменения функциональных задач издания (например, в сторону его дидактической направленности), несовпадение культурных кодов в системе разных европейских языков, технические сложности полиграфического производства. Все это приводило к появлению новых смыслов и значений - иногда неожиданных, но всегда важных, интересных и не случайных.

\section{Лumepamypa}

1. Сидоров А.А. Искусство русской книги XIX-XX веков // Книга в России: в 2 ч. / под ред. В.Я. Адарюкова, А.А. Сидорова. 2-е изд. Ч. II: Русская книга девятнадцатого века. М., 2008. С. 139-283. 
2. Die Kinderstube in 36 Bildernvon Oscar Pletsch: Die Handzeichnungen befindensich im Besitz Sr. Königl. Hoheit des Prinzen Friedrich Wilhelm Victor Albert von Preussen. In Holzgeschnitten von August Gaber. Hamburg, 1860. 84 s.

3. Gute Freundschaft: Eine Erzählung für Damen aber für Kleine in 21 Bildernerzählt von Oscar Pletsch. Berlin : Verlag der Weidmann schen Buchhandlung, 1865. $24 \mathrm{~s}$.

4. Kleines Volk: 20 Charakterzeichnungen von Oskar Pletsch. In Holzschnitt aus geführt von H. Bürkner. Mit Reimen von Friedrich Oldenberg. Berlin : Verlag d. Weidmannsch, 1865. 44 s.

5. Allerlei Schnik-Schnak Mit 48 Originalzeichnungen von Oscar Pletsch, in Holzgeschnitten von Prof. H. Bürkner. Leipzig : A. Dürr, 1866. 82 s.

6. Тесная дружба: Семейная хроника для крошечных дам / текст авт. «СтепкиРастрепки»; 24 рис. Оскара Плетча грав. на дер. проф. Г. Биркнером. СПб.; М. : М.О. Вольф, [1869]. 24 с.: ил.

7. Маленькие люди: [Стихи]: Текст авт. «Степки-растрепки»: 16 характеристических рисунков Оскара Плетча, гравир. на дереве проф. Г. Биркнером / [И. К-ев]. СПб. ; М. : М.О. Вольф, [1869]. [32] с.: ил.

8. Первые шаги жизни: Очерки с натуры [в стихах]: 32 характеристических рисунка Оскара Плетча, гравир. на дереве проф. Г. Биркнером: Текст авт. «Степки-Растрепки». СПб.; М. : М.О. Вольф, [187-?]. [2], 30 л.: ил.

9. Child-land: picture-pages for the little ones: containing nearly 200 designs by O. Pletch, M. Richter, \&c. London : S.W. Partridge \& C ${ }^{\circ}$ 1873. 255 p.

10. Дараган А.М. Елка: Подарок на Рождество. 10-е изд., с 120 политипажами Плетча, Фрелиха и других и 8 раскрашенными табл. по рис. Г. Пилатти. СПб. : М.О. Вольф, 1874. $90 \mathrm{c}$.

11. N.S. Der Maler der Kinderwelt // Wikisource. URL: https://de.wikisource.org/ wiki/Der_Maler_der_Kinderwelt (дата обращения: 20.12.2019).

12. Васильева Е., Пернатьев Ю. Вольф Маврикий Осипович // Тайны истории. Онлайн-архив. URL: https://secrethistory.su/946-volf-mavrikiy-osipovich.html (дата обращения: 20.12.2019).

13. Динерштейн Е.А. Петербургский издатель М.О. Вольф // Книга. Исследования и материалы / Всесоюзная книжная палата. 1999. Сб. 76. С. 126-164; Сб. 77. C. $155-185$.

14. Гофман Г. Степка-Растрепка. Рассказы для детей. [СПб.] : Тип. Х. Гинце, 1849. 16 л.

15. S.W. Partridge \& $C^{\circ} / /$ Bibliopolis. URL: https://books.bibliopolis.com/main/ find/publisher/S.W.\%20Partridge\%20\&\%20Co.html (дата обращения: 19.12.2019).

Text and Image: Conversation in Different Languages (Oscar Pletsch's Book Graphics in Germany, England, and Russia)

Tekst. Kniga. Knigoizdanie - Text. Book. Publishing, 2020, 24, pp. 113-133

DOI: $10.17223 / 23062061 / 24 / 6$ 
Ekaterina Yu. Romashina, Tula State Lev Tolstoy Pedagogical University (Tula, Russian Federation). E-mail: katerinro@yandex.ru

Keywords: children's literature, book graphics, text, visual narrative, Oscar Pletsch, translation.

In the second half of the 19th century, children's picture books became a mass phenomenon in European book publishing practice. The development of printing technology, the formation of psychology as scientific knowledge, the improvement of methods of educational interaction between adults and children led to the appearance of children's books not only for reading them aloud, but also for looking at pictures in them. However, the connections between the textual and visual narratives of books were not yet strong. Often, for economic reasons, the same illustrations were used in combination with different texts, and translations and reprints added discrepancies. In the article, this is illustrated by materials from the analysis of German, Russian, and English editions with drawings by Oscar Pletsch: Die Kinderstube (Hamburg, 1860), Gute Freundschaft (Berlin, 1865), Kleines Volk (Berlin, 1865), Allerlei Schnik-Schnak (Leipzig, 1866); Malen'kie Lyudi (St. Petersburg, 1869), Tesnaya Druzhba (St. Petersburg, 1869), Pervye Shagi Zhizni (St. Petersburg, 187?), Yolka (St. Petersburg, 1874); ChildLand (London, 1873). The plots Pletsch created are compared with the texts in three languages. As a result of the analysis, significant differences between the texts and the visual range of the editions were revealed. The article identifies the options of transforming meanings and interpreting drawings, reveals the tendency of their use for didactic purposes. The album Gute Freundschaft (initially containing only short captions to the drawings) acquired detailed poetic texts-monologues or dialogues of depicted children-in the Russian translation. The English publisher "scattered" the visual series: in Child-Land, the same drawings were placed randomly and mixed with other illustrations without observing any logic. The London edition contained prosaic texts, many of which did not coincide in meaning with the storyline of the original. The author (translator) sometimes interpreted the images "taken out of context" in a neutral way and sometimes added other (including sharply negative) characteristics to children's postures, gestures, and movements. In a number of cases, the texts emotionally "loaded" the images in a completely different way than the artist conceived: a gesture of greeting turned into a threat, expectation turned into boredom, and so on. It should be stressed that the Russian publisher Mauritius Wolf treated the German originals more carefully than his English colleagues from S.W. Partridge \& $\mathrm{C}^{\circ}$. The analysis of publications and the comparison of their verbal and visual plots allowed identifying the nature of the interrelation of text and image as a "conversation in different languages". The reason for the "discord" could be translation problems, general changes in the functional tasks of the publication (for example, towards a didactic purpose), the mismatch of cultural codes in the system of different European languages, and technical difficulties in printing. All this led to the emergence of new senses and meanings-sometimes unexpected, but always important, interesting and never accidental. 


\section{References}

1. Sidorov, A.A. (2008) Iskusstvo russkoy knigi XIX-XX vekov [The Russian book art of the 19th - 20th centuries]. In: Adaryukov, V.Ya. \& Sidorov, A.A. (eds) Kniga $v$ Rossii: v 2 ch. [Book in Russia: in 2 vols]. 2nd ed. Moscow: State Public Historical Library. pp. 139-283.

2. Pletsch, O. (1860) Die Kinderstube in 36 Bildernvon Oscar Pletsch: Die Handzeichnungen be-findensich im Besitz Sr. Königl. Hoheit des Prinzen Friedrich Wilhelm Victor Albert von Preussen. In Holzgeschnitten von August Gaber. Hamburg: [s.n.].

3. Anon. (1865) Gute Freundschaft: Eine Erzählung für Damen aber für Kleine in 21 Bild-ernerzählt von Oscar Pletsch. Berlin: Verlag der Weidmann schen Buchhandlung.

4. Oldenberg, F. \& Pletsch, O. (1865) Kleines Volk: 20 Charakterzeichnungen von. In Holzschnitt aus geführt von H. Bürkner. Mit Reimen von Friedrich Oldenberg. Berlin: Verlag d. Weidmannsch.

5. Pletsch, O. (1866) Allerlei Schnik-Schnak Mit 48 Originalzeichnungen von Oscar Pletsch, in Holzgeschnitten von Prof. H. Bürkner. Leipzig: A. Dürr.

6. Anon. (1869) Tesnaya druzhba: Semeynaya khronika dlya kroshechnykh dam [Close Friendship: A Family Chronicle for Tiny Ladies]. Text by the author of "StepkaRastrepka”, 24 designs by Oscar Pletsch engraved on wood by prof. G. Birkner. St. Petersburg; Moscow: M.O. Wolf.

7. Anon. (1869) Malen'kie lyudi [Little people]. 16 illustrations by Oscar Pletsch, engraved on wood by Prof. G. Birkner. St. Petersburg; Moscow: M.O. Wolf.

8. Anon. (187-?) Pervye shagi zhizni: Ocherki s natury [v stikhakh] [First steps in life: Sketches from nature [in verse]]. 32 designs by Oscar Pletsch, engraved on wood by Prof. G. Birkner. St. Petersburg; Moscow: M.O. Wolf.

9. Pletsch, O. (1873) Child-land: picture-pages for the little ones: containing nearly 200 designs by Oscar Pletch, M. Richter. London: S.W. Partridge \& $\mathrm{C}^{\circ}$.

10. Daragan, A.M. (1874) Elka: Podarok na Rozhdestvo [Christmas tree: Gift for Christmas]. 10th ed. with woodcuts by Pletscha, Frohlich et al. and 8 tables by pictures of G. Pilatti. St. Petersburg: M.O. Wolf.

11. N.S. (n.d.) Der Maler der Kinderwelt. [Online] Available from:

https://de.wikisource.org/wiki/Der_Maler_der_Kinderwelt (Accessed: 20th December 2019).

12. Vasilieva, E. \& Pernatiev, Yu. (n.d.) Vol'f Mavrikiy Osipovich [Wolf Mavriky Osipovich]. [Online] Available from: https://secrethistory.su/946-volf-mavrikiyosipovich.html (Accessed: 20th December 2019).

13. Dinershteyn, E.A. (1999) Peterburgskiy izdatel' M. O.Vol'f [Petersburg publisher M.O. Wolf]. In: Lensky, B.V. et al. (eds) Kniga. Issledovaniya i materialy [Book. Research and Materials]. Vol.76. pp. 126-164; Vol. 77. pp. 155-185.

14. Hoffmann, H. (1849) Stepka-Rastrepka. Rasskazy dlya detey [Shaggy Peter. Stories for Children]. [St. Peterburg]: Kh. Gintse.

15. Bibliopolis.com. (n.d.) S.W. Partridge \& C. [Online] Available from: https://books.bibliopolis.com/main/find/publisher/S.W.\%20Partridge\%20\&\%20Co.htm l (Accessed: 19th December 2019). 